\title{
Exotic Plants from Roman Waterlogged Sites in London
}

\author{
G. H. Willcox ${ }^{a}$
}

\begin{abstract}
An extensive range of plant remains was recovered from seven Roman sites in London where waterlogged conditions had resulted in good preservation. In the majority of cases the "artificial" nature of urban deposits precludes any objective ecological interpretation, since the allochthonous origin of the plant remains cannot be satisfactorily established. However, the presence of exotic plants in dated deposits is of both botanical and archaeological significance and is here artificially treated as an autonomous group. This varied group of plants (excluding carbonized cereals) is arranged according to their use and put in archaeological and botanical perspective. Species such as cucumber (Cucumis sativa), gold of pleasure (Camelina sativa), peach (Prunus persica), olive (Olea europaea) and millet (Panicum miliaceum) have not been recorded from Romano-British sites before. For many of these plants their status, either as introductions or imports, is uncertain. Whichever is the case, it is clear that a wide variety of economic plants was available in Roman London.
\end{abstract}

\section{Introduction}

Since the development of agriculture man has increasingly transported plants and plant food-stuffs away from their natural areas of distribution. Plants exotic to Britain are those which do not naturally occur in the indigenous flora, but have been brought by man from Europe, the Near East and more recently from the New World. In some cases they became established either as cultivated plants, ornamentals or weeds (i.e., introductions). In other cases dried or conserved items were transported and traded for consumption only (i.e., imports).

A rich assemblage of exotic plants has, over the past three years, been recovered from Roman waterlogged sites in London, indicating that increased contact with the Classical world made available a greater variety of economic plants both by importation and introduction. London does not appear to be an exception: for example, comparable finds are known from Caerwent and York, and of course Silchester is a well-documented example, but the economic and political status of London no doubt makes finds of imported or introduced plants more frequent.

The study of the history of domesticated plants is normally concerned with origins and subsequent morphological development due to the selective pressures of cultivation, but most of the plants dealt with here were established domesticates well before the Roman period and subsequent morphological development might best be described as refinement. Species such as walnut, mulberry and stone pine do not appear to have been greatly modified by selective pressures since the Roman period. Their presence in archaeological contexts is more significant than their morphological development, though where relevant, measurements of seeds are given (see Table 2). Weeds of arable land which spread with Classical farming practices are also included. However, in some cases the 


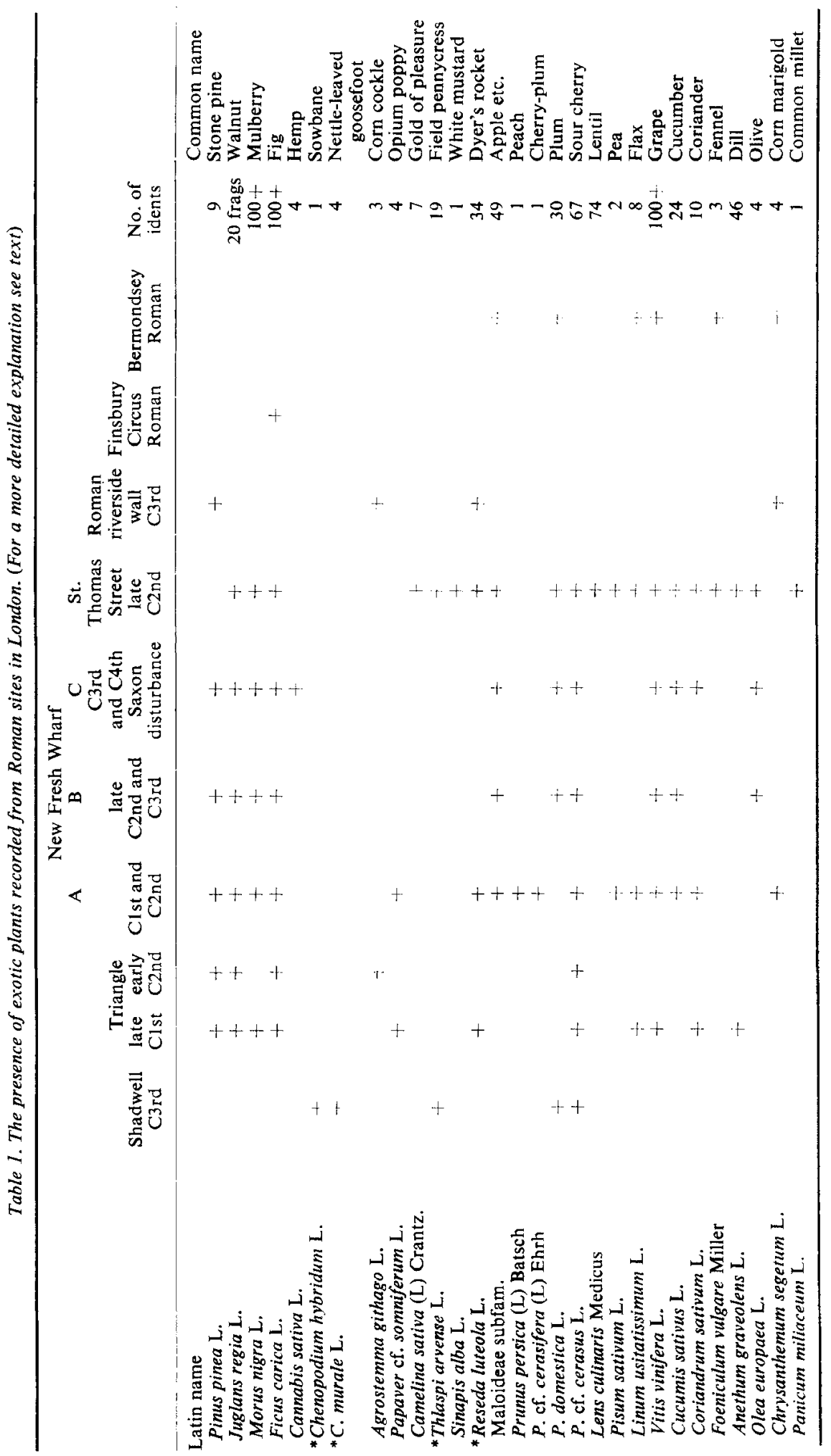


indigenous status of these plants has not been definitely established. The survival of macroscopic plant material (predominately seeds) can be attributed to the waterlogged nature of deposits which occur in low lying regions near the river Thames. Some specimens had become mineralized by calcium salts and the single specimen of millet (Panicum miliacelum) probably owes its survival to this process. Despite the urban nature of Roman London the plant assemblages obtained from waterlogged deposits contained a rich and varied flora. consisting of species associated with waste ground, grassland, pasture. marshland, riverbanks and agriculture. They may include plants known to have been utilized by man for a variety of purposes, e.g., as foodstuffs, drugs, medicines, and various industrial uses (the samples from St. Thomas Street are exceptional in that they contain so few of these plants, see below). However, the nature of the deposits and the complexity of urban deposition preclude any objective ecological interpretation in the majority of cases. Ecological principles which can be applied to natural deposits are here disrupted due to differential deposition and decomposition, residuality, adventitiously misplaced material and reworking of deposits, all predominantly human factors, while dispersal of seeds in faeces of animals such as birds and cattle. on clothing, by wind, water and man can rarely be evaluated.

The presence of exotic plants in dated deposits, however, is of both botanical and archacological significance, hecause it provides evidence of the history of vegetation in relation to human exploitation and yields evidence with which one can attempt to reconstruct generalities about plant husbandry. Since the deposits in question are largely "artificial" the components and relative abundance of cultivated plants will be a function of the archaeological feature(s) and not representative of the true economy in question. Thus any quantitative synthesis should be based on presence regardless of abundance: in other words the frequency of a taxon is dependent on its presence in an individual archaeological context. Presence-analysis has been summarized by Hubbard (1976).

\section{Methods}

The heterogeneous group of plant remains reported here was recovered by two different methods. Some of the material was recovered as a by-product of the extraction of animal bone and carbonized material by wet-sieving combined with water flotation, using $1 \mathrm{~mm}$ and 500 micron sieves respectively. Results have shown that this method is selective, but nevertheless it was useful for unconsolidated deposits with a high percentage of very coarse mineral matter typical of the re-worked Flood Plain Terrace. Samples from New Fresh Wharf (see below) and Shadwell were processed in this way. Beciause samples of at least $50 \mathrm{~kg}$ can be processed many of the rarer seeds, pine cone bracts and fruit stones collected from the $1 \mathrm{~mm}$ sieve would have otherwise been missed. A more controlled method was used for the remaining sites where smaller samples of $1-5 \mathrm{~kg}$ were disaggregated using dilute hydrogen peroxide, followed by washing over a 300 micron sieve; what was retained on the sieve was sorted for seeds and seed fragments and then stored in alcohol (industrial methylated spirits). In some cases the seeds were dried at room temperature but subsequent distortion takes place when seeds are treated in this way.

\section{The Nature of the Sites}

New Fresh Wharf (Grid ref. TQ 32448067 ; Schofield \& Miller, 1976) is situated just south of Upper Thames Street and west of Billingsgate fish market. The site was excavated to c. $3 \mathrm{~m}$ below Ordnance Datum Newlyn exposing a Roman waterfront of late 2 nd century date which had been well preserved as a result of waterlogging caused by the rising levels of the Thames (Willcox, 1975). Samples were taken from three different deposits. Deposit A (see Table 1) was immediately below the waterfront and is of first to mid-2nd century 
Table 2. Measurements of relevant seeds of cultivated plants $(\mathrm{mm})$

\begin{tabular}{|c|c|c|c|c|c|c|c|c|c|c|c|c|}
\hline & \multicolumn{3}{|c|}{ Length } & \multicolumn{3}{|c|}{ Breadth } & \multicolumn{3}{|c|}{ Thickness } & \multicolumn{3}{|c|}{ Diameter } \\
\hline & mean & $\max$ & $\min$. & mean & $\max$ & $\min$. & mean & $\max$ & $\min$. & mean & $\max$. & $\min$. \\
\hline Cannabis sativa & $4 \cdot 2$ & & & $3 \cdot 1$ & & & & & & & & \\
\hline Camelina sativa & $1 \cdot 7$ & $1 \cdot 9$ & $1 \cdot 6$ & $1 \cdot 1$ & $1 \cdot 2$ & $1 \cdot 0$ & $1 \cdot 0$ & $1 \cdot 1$ & 0.9 & & & \\
\hline Sinapis alba & & & & & & & & & & $2 \cdot 2$ & & \\
\hline Prunus persica & $25 \cdot 5$ & & & $20 \cdot 5$ & & & $14 \cdot 5$ & & & & & \\
\hline$P$. cf. cerasifera & $10 \cdot 0$ & & & $8 \cdot 1$ & & & $7 \cdot 4$ & & & & & \\
\hline P. domestica & & $20 \cdot 2$ & $11 \cdot 3$ & & $11 \cdot 5$ & $7 \cdot 7$ & & $8 \cdot 2$ & $7 \cdot 2$ & & & \\
\hline P. cf. cerasus & $8 \cdot 1$ & $8 \cdot 7$ & $5 \cdot 9$ & 6.6 & $8 \cdot 2$ & $5 \cdot 8$ & $6 \cdot 5$ & $7 \cdot 2$ & $4 \cdot 2$ & & & \\
\hline Lens culinaris & & & & & & & $2 \cdot 1$ & $2 \cdot 5$ & 1.8 & $4 \cdot 3$ & $5 \cdot 0$ & $4 \cdot 0$ \\
\hline Pisum sativum & $5 \cdot 1$ & & & $4 \cdot 9$ & & & $4 \cdot 4$ & & & & & \\
\hline \multicolumn{13}{|l|}{ Linum } \\
\hline usitatissimum & 3.9 & $4 \cdot 2$ & $3 \cdot 4$ & $2 \cdot 1$ & $2 \cdot 3$ & 1.9 & 0.9 & $1 \cdot 0$ & $0 \cdot 8$ & & & \\
\hline Vitis vinifera & $7 \cdot 2$ & $7 \cdot 9$ & $5 \cdot 6$ & $4 \cdot 1$ & $5 \cdot 2$ & $3 \cdot 5$ & $2 \cdot 4$ & $3 \cdot 2$ & $2 \cdot 1$ & & & \\
\hline Cucumis sativum & $8 \cdot \overline{0}$ & $9 \cdot 1$ & $6 \cdot 8$ & $3 \cdot 3$ & $3 \cdot 6$ & $3 \cdot 1$ & $1 \cdot 0$ & 1.2 & 0.9 & & & \\
\hline Coriandrum sativum & $3 \cdot 5$ & $3 \cdot 8$ & $2 \cdot 9$ & & & & & & & $2 \cdot 5$ & $2 \cdot 9$ & $2 \cdot 2$ \\
\hline Foeniculum vulgare & $4 \cdot 6$ & $5 \cdot 7$ & $4 \cdot 4$ & $2 \cdot 3$ & $2 \cdot 5$ & 1.9 & $2 \cdot 0$ & $2 \cdot 2$ & $2 \cdot 1$ & & & \\
\hline Anethum graveolens & $4 \cdot 1$ & $4 \cdot 4$ & $3 \cdot 2$ & $2 \cdot 3$ & $2 \cdot 4$ & $2 \cdot 1$ & $0 \cdot 8$ & $1 \cdot 1$ & $0 \cdot 4$ & & & \\
\hline Olea europaea & $10 \cdot 0$ & $12 \cdot 4$ & $7 \cdot 5$ & & & & & & & $5 \cdot 2$ & $5 \cdot 6$ & $4 \cdot 6$ \\
\hline Panicum miliaceum & $2 \cdot 6$ & & & $1 \cdot 9$ & & & $1 \cdot 2$ & & & & & \\
\hline
\end{tabular}

Cannabis sativa was too compressed to give an accurate thickness measurement. Where only a single specimen was measured results are given under the mean column.

date, composed mainly of reworked river-gravels. B came from silting within the structure and is of late second and third century date, while $C$ lay over this and consisted of 3 rd and 4th century silting. This last layer was disturbed during the Saxon period when part of the waterfront was robbed, so there is a risk of contamination from the Saxon period, and, since it is known that amphorae were imported during this later period the contents of this upper layer should be treated with caution. The inclusion of plant remains in these deposits probably is the result of casual dumping and accidental waste.

In contrast, at St. Thomas Street, Southwark (Grid ref. TQ 3274 8019) which is situated just south of London Bridge Station, near Guy's Hospital, samples were taken from a single, late 2nd century, timber-lined pit that was divided into four compartments. Preservation of organic matter was partly due to waterlogging and partly to mineralization by calcium salts. The circumstances of deposition and function of the pit cannot be definitely established, though it is possible that after it went out of use it was rapidly filled with (? kitchen) refuse. The dearth of weeds usually associated with archaeological deposits may imply that it was covered, although the time of year and the nature of the secondary fill would also have had a marked influence.

One sample also described is from the Roman Riverside Wall excavation (Grid ref. TQ 319 809) which was situated just east of the Mermaid Theatre on the line of Upper Thames Street. Here a thin waterlogged organic layer of 3 rd century date contained a mixture of both terrestrial and freshwater mollusca indicating that the river may have flooded this area on occasion. The inclusion of plant remains can be compared with those from New Fresh Wharf.

Casual dumping probably also produced the assemblage from Triangle (Grid ref. TQ 3301 8069), which is just north of New Fresh Wharf, but at a higher elevation where Roman revetments had been built into the steeply rising escarpment of the Taplow Terrace. Samples were taken from urban debris which had accumulated in the 1st and 2nd century AD behind the revetments. 
At Shadwell (Grid ref. 347 807) one mile east of the Roman city, a feature interpreted as a water storage tank associated with a late 3 rd century signal tower was sampled (Johnson. 1975 ) and found to contain a rich collection of agricultural weeds, but few cultivated plants. Also included in Table 1 are botanical records from two previously published sites, one located at Finsbury Circus (Lambert, 1920) and the other at Tooley Street in Bermondsey (Kennard \& Warren, 1903). The former site is located in the area of the headwaters of the Walbrook, the latter from silt deposits on the south bank.

\section{The Plants}

Table 1 gives the list of exotic plants recorded from Roman waterlogged sites to date. The ordering of species and nomenclature follows the Flora Europaea (Tutin et al., 1964-75). The sites and periods are given at the top of the table, with presence indicated by a cross against each species. The total number of separate identifications are given in the far right hand column. Those plants whose status as exotics is in doubl are marked with an asterisk.

In discussing the plants below I have departed from the systematic ordering by classification and placed them in artificial groups, which are relevant in terms of utilization and economy. Notes on morphology are also included where relevant, and photographs of significant species can be found in Figures 1-4. Measurements of seeds are given in Table 2. Common names are used in the text, although where they are not explicit Latin names are also given.

\section{Imported Pines}

Nuts, bracts and whole cones of the stone pine have been recovered from several sites in London other than those mentioned in Table 1. These other localities include the Royal Exchange and National Safe Deposit Company premises (Norman \& Reader, 1904), the Temple of Mithras (Grimes, 1968) and St. Swithin's House (Museum of London Accession No. 24195). Finds have also been made at a temple of Mithras at Carrawburgh on the Antonine Wall (Richmond et al., 1951), where charred pine cones of this species were found, suggesting use as an altar fucl. Further finds come from Chew Park, Somerset (Godwin, 1975) and Verulamium (Wheeler, 1936). This species of pine is native to the Mediterranean region and although healthy trees grow in Britain today, we have no evidence of when it was introduced. Probably whole cones were imported to be used as votive offerings in temples, with which they have frequently been associated. Importation of cones is also suggested, but not confirmed, by a find of at least one hundred of them in the Madrague de Giens wreck (1st century BC) recently excavated off the Mediterranean coast near Toulon (Patrice Pomey, personal communication), showing that pine cones were indeed objects of trade in the Roman period.

Wood belonging to the Pinaceae has also been recovered from several sites in London in the form of writing tablets, barrels and small objects, but as yet no reliable identifications have been made.

\section{The Spices}

Dill, coriander and fennel are all members of the Umbelliferae and originally came from southern Europe and south-west Asia. Like many other herbs and spices they have found their way to the more northern parts of Europe where they have become established. Coriander has been recovered in Britain from a Late Bronze Age context and three other Roman sites-Silchester, Caerwent and Godmanchester (Godwin, 1975). In the majority of cases the seeds from London were in good condition, comparing well with modern reference material although smaller (see Table 2). Dill was, according to Apicius (Rosenbaum \& Flower, 1958), a commonly used culinary plant in the Classical world. It has also 


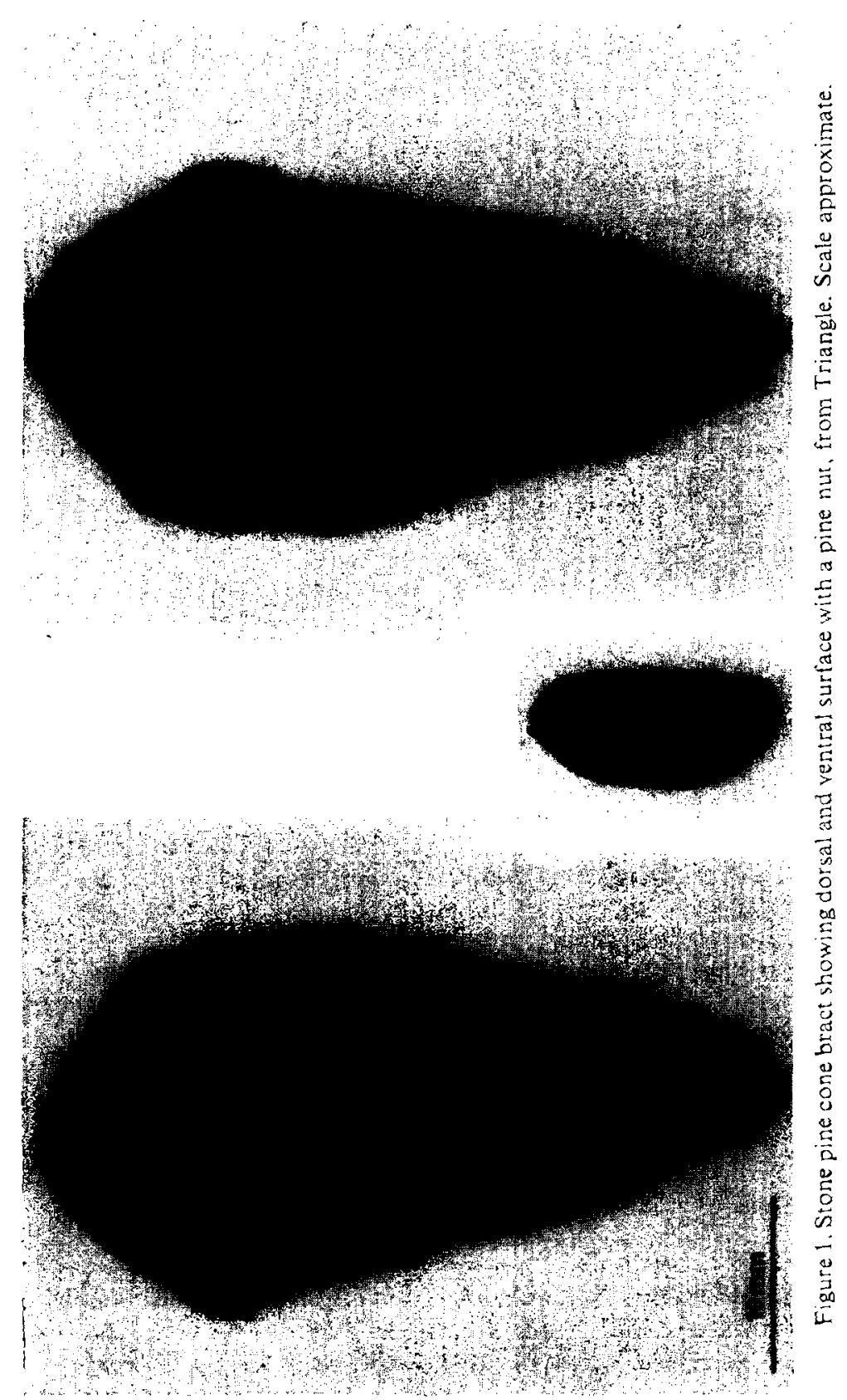




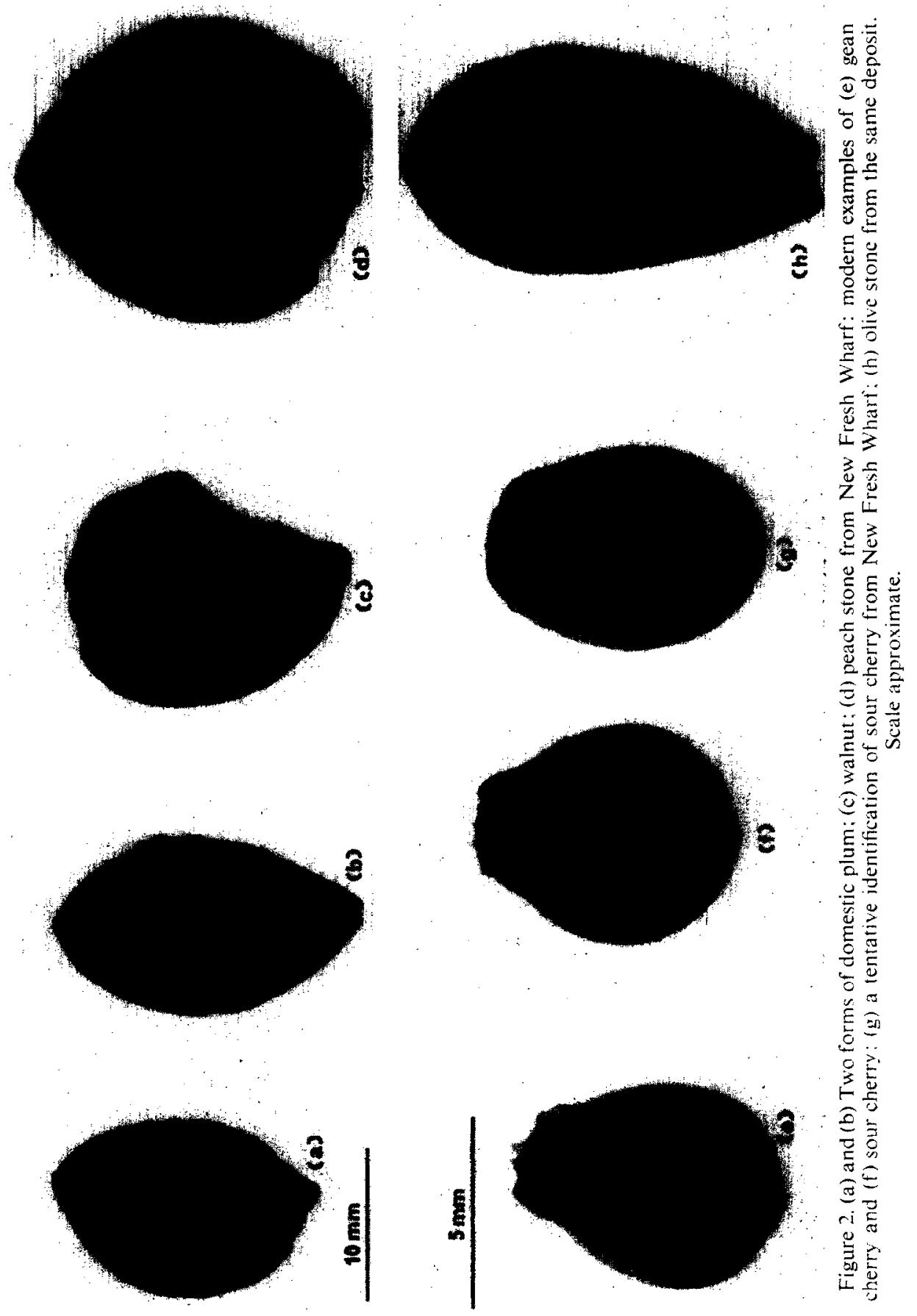



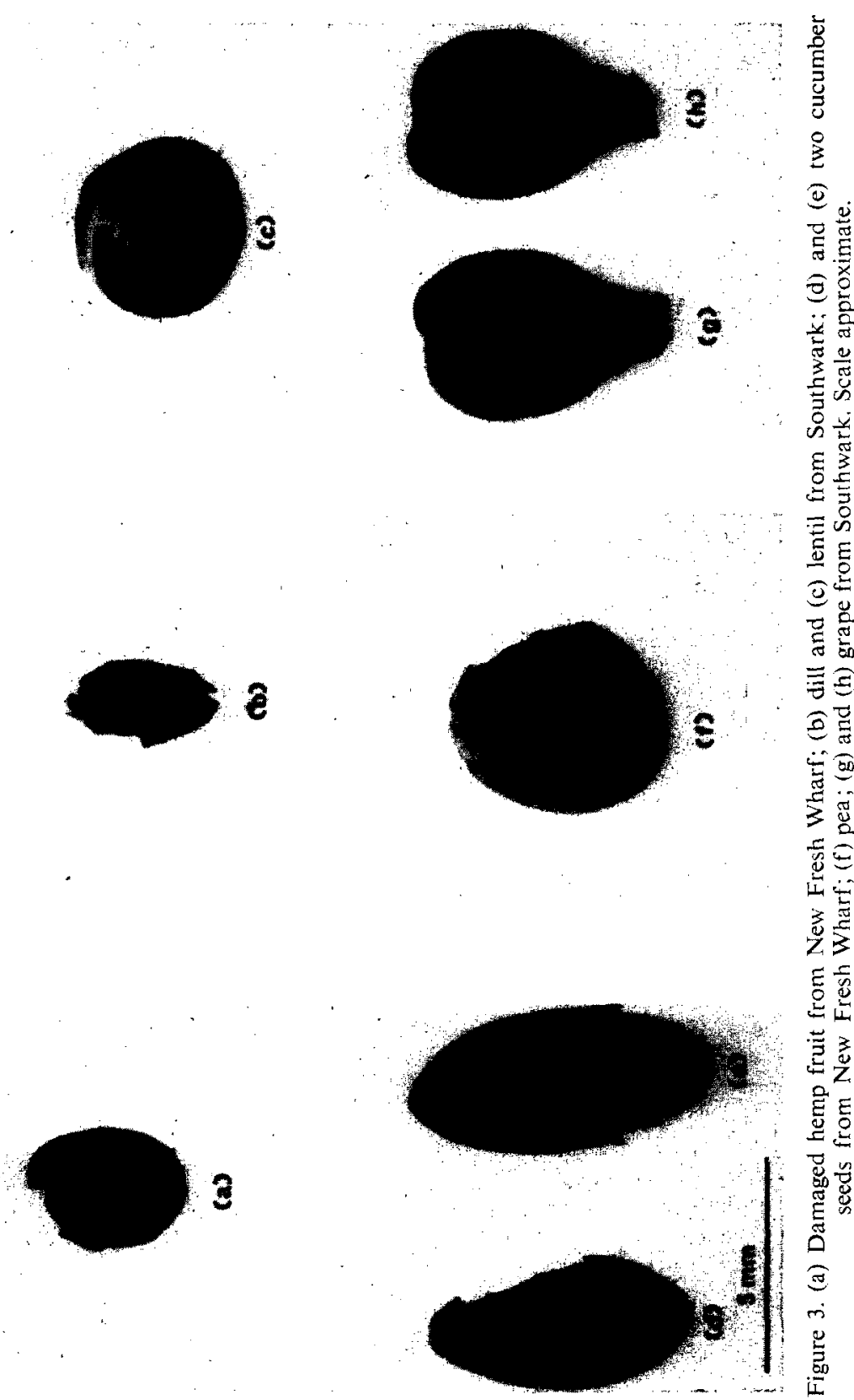
EXOTIC PLANTS FROM ROMAN WATER LOGGED SITES 277
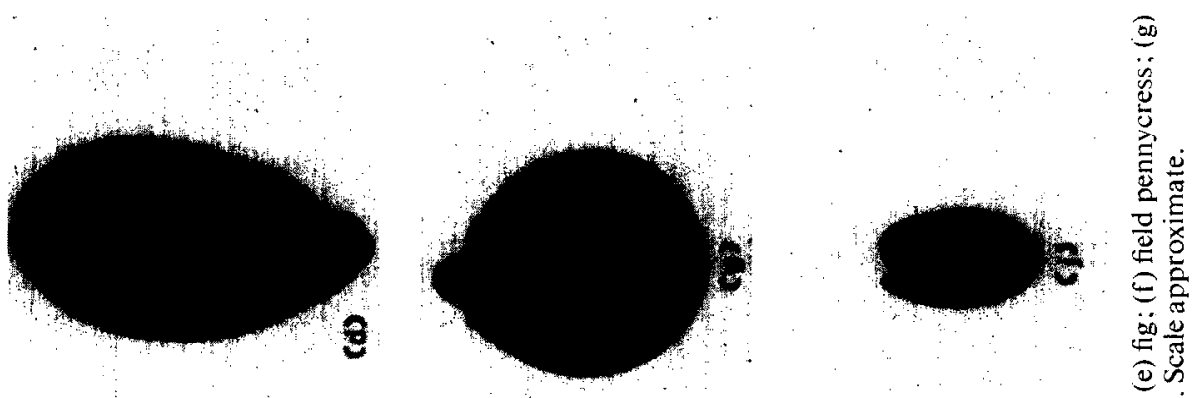

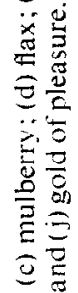
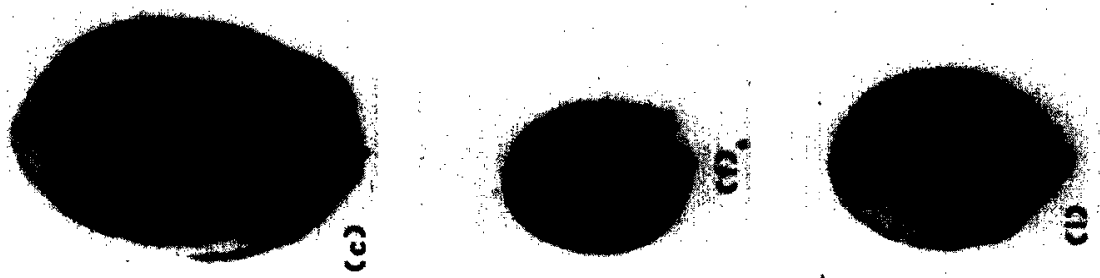

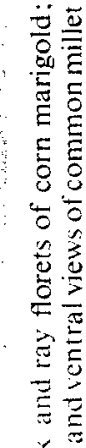
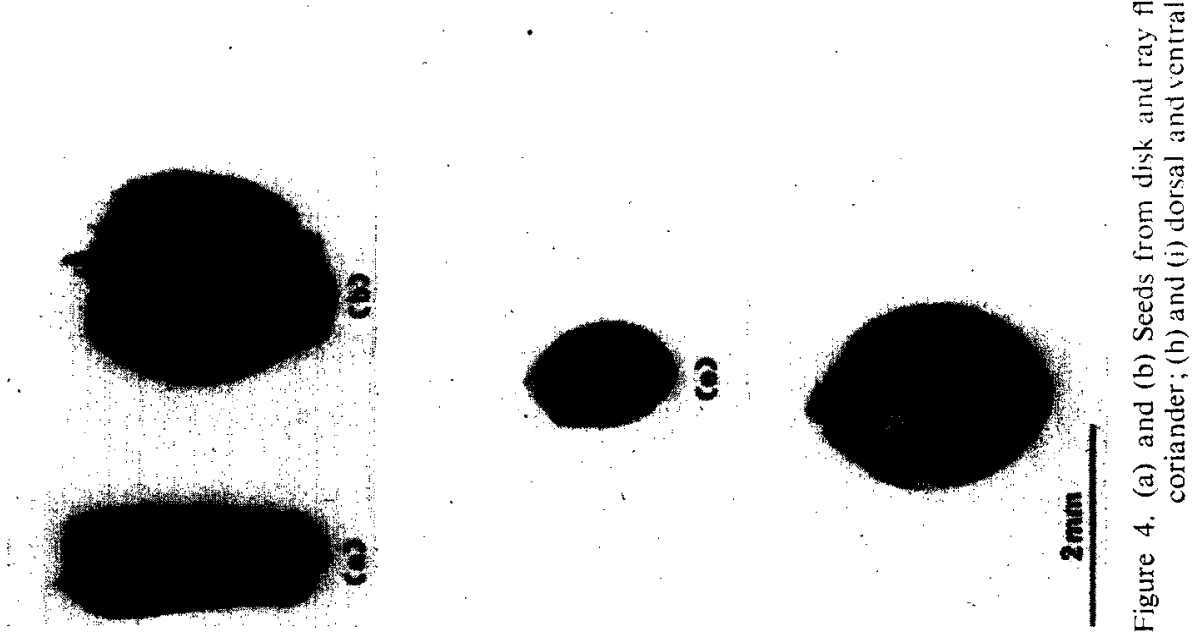
been found at Caerwent and Silchester and more recently from Caernarvon (G. Hillman, personal communication). In some cases the outer layers, including the lateral margins, of the mericarps from St. Thomas Street had become detached or decomposed, exposing the four dorsal and two ventral oil ducts (vittae). Fennel appears to be less common than either dill or coriander, but has also been recovered from Silchester. Mustard (Sinapis $a l b a$ ) may have been used as a spice or condiment, and at St. Thomas Street this would appear probable, although it may merely represent an introduced weed or ruderal. The single seed recovered measured $2 \cdot 2 \mathrm{~mm}$ in diameter. Vaughan (1970) gives a measurement of $2.5 \mathrm{~mm}$ for modern material, and also describes in detail the structure of this and similar seeds with which it might easily be confused, in particular $S$. nigra L. and similar Brassica spp.

The majority of spices and the herbs (e.g., the Labiatae), would very rarely be represented in the archaeological record since parts other than the seeds are used and pollen grains, for example, if they were present, could not be identified to species. Thus we should assume that those which have been recognized form only part of a wider repertoire of condiments.

\section{The Succulent Fruits}

Within this group all the edible succulent parts of the fruit decompose, leaving the resistant seeds, which may in some cases be derived from coprolites. The cherries and maloids could not readily be identified to the specific level, due to the considerable variation in morphology exhibited by both ancient and modern material and the decomposed state of the archaeological material. The maloid group includes apple, pear and quince, any of which may have been present. The stones of the indigenous gean cherry (Prunus avium $2 n=16$ ) and the exotic sour cherry ( $P$. cerasus, centre of diversity uncertain, $2 n==32$ ) while having different genotypes are not easily distinguished using the morphology of their endocarps. Modern cultivated forms of these species are not necessarily morphologically comparable with ancient material; for example, the large stones of the modern cultivated gean cherry with large protruding lips either side of the suture were not present. Further complications arise because hybrids can arise between these two species (Stace, 1975). The stones recovered most closely resembled modern cultivated forms of sour cherry on morphological grounds though its genotype may not be comparable (i.e., it could be $P$. avium form): the identification accordingly is tentative. There is no evidence for the prehistoric occurrence of the cultivated cherry in Britain. The domestic plum (Prunus domestica $2 n=48$ ) arose from a hybridization between the sloe ( $P$. spinosa L. $2 n=32$ ), a ubiquitous plant in Europe and the Near East and the cherry-plum ( $P$. cerasifera $L$. $2 n=16$ ), a native of the Near East. The resulting polyploid is made up of several rather ill-defined subspecies, and intermediates occur (Clapham et al., 1962). These subspecies cannot be satisfactorily distinguished in the palaeobotanical material. Some of the smaller stones resembled bullace ( $P$. domestica insititia L., Schneid) and those of intermediate size, damson. However, the domesticated plum will back-cross with its wild progenitors giving $2 n=40$.

The identification of the other types of stones and pips presented no problem since both their morphology and genetic constitution have remained stable, though in some cases size variation may be significant in relation to development and selection by man. Olives are an attested amphora-borne commodity which must have been imported. Four stones were recovered, one from St. Thomas Street and three from New Fresh Wharf. Two of these stones were unusually small.

Fig seeds are the most common of all cultivated seeds in London, both numerically because the fruit produces a copious quantity, but also, more importantly, by presence. These figs were, no doubt, imported as dried fruit, but it should be noted that seeds can 
arise in fruits from plants grown in this country without the presence of the fertilizing agent (which in this case is a wasp not known from the British Isles in the Roman period) by parthenogenesis (Hill, 1971). The seeds produced in this way are generally somewhat vestigial, while those recovered from sites in London are fully formed: without postulating climatic change we must assume they were imported. Fig has also been recorded from Roman levels at Silchester and Verulamium.

Mulberry, a native of Asia, on the other hand was more probably an introduction. Being a very soft fruit it does not travel well and there are no records of it being conserved in antiquity. Godwin (1975) is of the opinion that the mulberry found at Silchester was an introduction.

Grape pips of the cultivated type have been recovered from several urban sites in Britain, e.g., Silchester, Gloucester (Godwin, 1975), York and Doncaster (Addyman et al., 1975). There is tentative evidence for viticulture in southern Britain (Addyman et al., ihid.), but, no doubt, there was importation as well. Viticulture has been used as a climatic indicator for the Medieval period, but socio-economic factors tend to over-shadow any climatic interpretation.

Peach, not reported from Roman levels in Britain before, could have been grown here. but is more probably an importation.

\section{V'egetahles}

The majority of these plants would leave little or no evidence in the archaeological record. Seeds belonging to the genus Brassica (which includes cabbage, sprouts, cauliflower, turnip and swede) are neither definitely exotic nor necessarily cultivated and although they were present in some samples I have not recorded them here. Cucumber, ultimately a native of Africa (Whitaker, 1962) is common on two sites in London and Classical authors mention it as a commonly grown garden plant in the Roman world. having spread from a sccondary area of diversity in India. It is rare in the archaeological record, but it has been recorded from the medieval site of Novgorod (Thompson, 1967). The infrequency of the seeds of this plant may be due to the fact that, as is customary today, the fruits are eaten before they have fully ripened. It is possible that in more northern climates it is advantageous to allow them to develop fully. It is also possible that they were being grown to provide seed stock.

\section{The Pulses}

Peas have been reported from four other Roman sites in Britain apart from St. Thomas Street and New Fresh Wharf (Godwin, 1975: Hillman, op. cit.) which would seem to establish the plant as a Roman or possibly prehistoric introduction. In Holland they have not been recorded until the medieval period but as van Zeist (1970) points out, the Bandkeramik farmers in the south-east of the country probably grew peas. Lentils, of which a large number came from St. Thomas Street, would be difficult to establish under present day climatic conditions. Helbaek (1964) reported carbonized specimens from Wales and suggested two possible explanations for its presence; either it was accidentally imported with the grain found with it, or it was introduced. The lentils from Southwark were not associated with grain, suggesting a direct import or an attempt at cultivation.

\section{Walnut}

Finds of this characteristically wrinkled nut have been made from three sites in London. Godwin (1975) suggests that it was introduced by the Romans, on the basis of charcoal from Rotherley and evidence from the Netherlands. Yet finds throughout the country are surprisingly scarce, possibly because it was slow to become established. 


\section{Oil and fibre plants}

Hemp and flax, though not commonly grown in this country today, were economically important plants in antiquity. Flax is known from prehistoric contexts in England, where it was thought to have been cultivated for linseed oil. By the Roman period hemp and flax were cultivated in Europe for their bast fibre used in the manufacture of rope, hessian and linen. Flax seeds have been identified from four other Roman sites in Britain, and also from Roman sites in Holland (van Zeist, 1974). The eight examples from London were well preserved, though in places the testa had decomposed, exposing the endosperm, the structure of which is described by Vaughan (1970).

The identification of hemp seeds from New Fresh Wharf should be treated with caution hecause they were present in deposit $\mathrm{C}$ (see Table 1) which as noted earlier was disturbed in the Saxon period and may therefore be contaminated. Hemp cultivation in the Saxon period has been identified by pollen analysis, and fibre is known from Bar Hill, a fort on the Antonine Wall (Godwin, 1967). It was grown by the Romans for both oil and fibre but appears to be rare in the northern provinces. Gold of pleasure has been identified from prehistoric and Roman contexts in Holland (van Zeist, 1974), but not, as far as I am aware, from Britain. Today it grows as an occasional weed in wheat, flax and lucerne fields (Clapham et al., 1962), but it was cultivated in the past for its oil-yielding seeds. Its known association with flax combined with the presence of field pennycress (see Table 1), also a common weed of flax, suggests an explanation for its presence in the St. Thomas Street pit.

\section{Cereals}

No uncarbonized cereals were recovered from these sites in the waterlogged state with the exception of a single grain of millet. Carbonized grain was only occasionally encountered and is beyond the scope of this paper. The single seed of millet (Panicum miliaceum) was identified by R. N. L. B. Hubbard of the Institute of Archaeology. It has been found in northern Europe in the prehistoric and Roman period (van Zeist, 1974), and was known to have been cultivated in medieval times. Its absence from Britain has long been a mystery (Helbaek, 1952). However, the find of a single grain can have little significance.

\section{The Weeds}

The introduction and extension of weeds in the Romano-British period resulted from the expansion of a more highly developed agricultural system, road building, increased transport of provisions and increased movements of people. These were all powerful agents of dispersal. Godwin's (1975) list, of weeds first appearing in Romano-British contexts illustrates the effect of Roman farming on the weed population. However, as he points out, some of these may in time be recorded from earlier deposits.

Unlike, for example, a carbonized assemblage from a rural context associated with a particular crop plant, the presence of weeds and ruderals in urban waterlogged deposits is of little ecological or economic significance for reasons outlined above (p. 271). Those weeds which are exotic have been included. All are plants of arable land and may have been deposited from fodder for cattle or horses, but could have been grown locally. Dyer's rocket and opium poppy may have had economic significance. The latter is usually closely associated with Roman sites and can be used as a condiment. The former, apart from being a weed, is used as a dye plant and unlike woad (Isatis tinctoria) its seeds occur at the place of dyeing. It is probably native to the south-western region of central Europe. Corncockle and corn marigold are common on Roman sites. Both come from the eastern Mediterranean region. The three remaining weeds could be native, and as mentioned above field pennycress is usually associated with flax. 


\section{Conclusion}

Finds of subfossil exotic plant remains from the Roman period in Britain have come predominantly from urban sites. This may reflect the availability of suitable deposits more than the actual distribution of these plants in this period, because urban centres are characteristically situated in low lying regions adjacent to rivers where waterlogged deposits have been buried beneath accumulating urban debris. Socio-economic factors tend to govern the plant assemblages and therefore greatly diminish environmental significance. Thus, for example, viticulture may have only been practised in southern England, yet one might expect finds from the north, as a result of trade. For such reasons it would be unwarrantable to infer any climatic change.

There is no doubt that trade in foodstuffs took place on a wide scale at this time. A large quantity of foreign amphorae have been recovered from lst and 2nd century AD levels in London. The majority were from Italy and Iberia and were used as containers for wine and olive oil, but the contents of the remainder are unknown. Callender (1965) mentions olives, apples, cherries, plums, peaches, figs, dates, beans, lentils and nuts as amphoraborne commodities known to us from literary evidence. Exports from Spain (Parker, 1973 ) according to written records included olives, wheat, barley, apples, pears, quinces. cherries. figs, nuts, lentils and vegetable dyes. Archaeobotanical evidence outside England is scarce, even where work has been carried out, as for example in the Netherlands, but here the Romanizing influences may have been less marked. On the Rhine at Neuss (Knörzer, 1966) carbonized remains of rice, chick peas, and figs were recorded; these appear to be imports. Evidence of this kind indicates that one should be cautious before stating that a plant has been introduced and cultivated. However, in the case of mulberry, or even perhaps stone pine, the wide distribution of finds in London is a possible indication of cultivation. Pliny states that cherry was introduced to Britain in AD 47 and if we are to be suspicious of earlier archaeobotanical identifications (Godwin, 1975). then this may represent the introduction of the cultivated sour cherry (Prumus. (erastis).

The absence of certain species from the archaeobotanical record does not necessarily imply they were not in use. We may assume, for example, that a number of vegetables belonging to the Brassica genus, e.g., turnip, rape and a variety of cabbages, could have been brought across from Gaul where they were in use (Finberg, 1972). Radish may also be included in this group. Other plants which appear to be native to Britain were quite possibly cultivated in the Roman period, e.g., corn salad (Valerianella locusta (L.). Betche). Finds of native plants such as elderberry, sloe and blackbersy, were common and they were, no doubt, gathered from the wild, and so are beyond the scope of this article. Further examination of samples should produce a more comprehensive list of exotic weeds.

The rich assemblage of exotic plants from Roman London contains species such as cucumber, gold of pleasure, peach, olive and millet which have not previously been recorded from Britain in this period. On the other hand, almond, sweet chestnut and possibly portugal laurel (Prunus lusitanica L.) have been found elsewhere in Britain. For many, their status either as introductions or imports for the Roman period is not certain. Whichever the case, it is clear that a wide variety of economic plants came into use for the first time in Romano-British times.

\section{Acknowledgements}

I am indebted to Professor G. W. Dimbleby, Gordon Hillman and Richard Hubbard for their help and criticism during the preparation of this work, and to members of the Museum staff who assisted me, particularly Trevor Hurst who took the photographs. 


\section{References}

Addyman, P. V., Hood, J. S. R., Kenward, H. K., MacGregor, A. \& Williams, D. (1976). Palaeoclimate in urban environmental archaeology at York, Fngland: problems and potential. World Archaeology 8, 220-233.

Callender, M. H. (1965). Roman Amphorae. Oxford University Press.

Clapham, A. R., Tutin, T. G. \& Warburg, F. F. (1962). Flora of the Rritish Isles, 2nd edn. Cambridge University Press.

Finberg, H. R. R. (Ed.) (1972). The Agricultural History of England and Wales, Vol 1. Cambridge University Press.

Godwin, H. (1967). The ancient cultivation of hemp. Antiquity 45, 42 \& 137.

Godwin, Sir H. (1975). History of the British Flora, 2nd edn. Cambridge University Press.

Grimes, W. F. (1968). The Excavation of Roman and Medieval London. I.ondon: Routledge and Kegan Paul.

Helbaek, H. (1952). Preserved apples and Panicum in the prehistoric site at Norre Sandegaard in Bornholm. Acta Archaeologica 23, 107-115.

Helbaek, H. (1964). The Isca grain, a Roman plant introduction in Britain. New Phytologist 63, $158-164$.

Hill, D. S. (1971). Wasps and figs. New Scientist, 15 April 1971, 144-146.

Hubbard, R. N. L. B. (1976). Crops and climate in prehistoric Europe. World Archaeology 8, 159-168.

Johnson, T. (1975). A Roman signal tower at Shadwell, E.1 -an interim note. Transactions of the London and Middlesex Archaeological Society 26, 278-280.

Kennard, A. \& Warren, S. (1903). On a section of the Thames alluvium in Bermondsey. Geological Magazine 10, 456-460.

Knörzer, K.-H. (1966). Uber Funde römische Importfrüchte in Novaesium (Neuss/Rh.). Bonner Jahrbücher 166, 424-443.

Lambert, F. (1920). Some recent excavations in London. Archoeologia 71, 55-122.

Norman, P. \& Reader, F. W. (1904). Recent discoveries in connexion with Roman London. Archaeologia 60, 169-250.

Parker, A. J. (1973). The evidence provided by underwater archaeology for Roman trade in the Western Mediterranean. In (D. J. Blackmand, Ed.) Marine Archaeology. Colston Papers 23, 361-382.

Richmond, I. A., Gillam, J. P. \& Birley, E. (1951). The Temple of Mithras at Carrawburgh. Archaeologia Aelinana, 4th Series, 29, 1-92.

Rosenbaum, E. \& Flower, B. (1958). The Roman Cookery Book. (Translation of Apicius). London: Harrap.

Schofield, J. \& Miller, L. (1976). New Fresh Wharf: the Roman waterfront. London Archaeologist 2, 390-394.

Stace, C. A. (1975). Hybridization and the flora of the British Isles. London: Academic Press.

Thompson, M. W. (1967). Novgorod the Great. London: Evelyn, Adams and Mackay.

Tutin, T. G., Heywood, V. H., Burges, N. A., Valentine, D. H., Walters, S. M. \& Webb, A. D. (1964 75). Flora Europa 1-4. Cambridge University Press.

Vaughan, J. L. (1970). The Structure and Utilization of Oil Seeds. London: Chapman \& Hall.

Wheeler, R. E. M. \& Wheeler, T. V. (1936). Verulamium: A Belgic and two Roman Cities. Oxford: Society of Antiquaries.

Whitaker, T. W. \& Davis, G. N. (1962). Cucurbits. London: Leonard Hill.

Willcox, G. H. (1975). Problems and possible conclusions related to the archaeology and history of the Thames. Transactions of the London and Middlesex Archaeological Society 26, 285-292.

van Zeist, W. (1970). Prehistoric and early historic food plants in the Netherlands. Palaeohistoria 14, 4I-173.

van Zeist, W. (1974). Palaeobotanical studies of settlement sites in the coastal area of the Netherlands. Palaeohistoria 16, 223-369. 